\title{
H2AC13 Gene
}

National Cancer Institute

\section{Source}

National Cancer Institute. H2AC13 Gene. NCI Thesaurus. Code C162900.

This gene is involved in histone-mediated transcription regulation, DNA repair, DNA

replication and chromosomal stability. 